\author{
В.В. Мегельбей ${ }^{1}$, С.В. Нєкрасов ${ }^{1}$, Д.С. Іценко ${ }^{2}$, К.А. Шептуха ${ }^{1}$ \\ ${ }^{1}$ Харківський наиіональний університет Повітряних Сил ім. І. Кожедуба, Харків \\ ${ }^{2}$ Військово-наукове управління Генерального штабу Збройних Сил Украӥни, Київ
}

\title{
МЕТОДИКА ОЦІНКИ ВІДПОВІДНОСТІ ВИМОГАМ БЕЗПЕКИ УМОВ ПРОВЕДЕННЯ БОЙОВИХ СТРІЛЬБ ЗЕНІТНИМИ РАКЕТНИМИ КОМПЛЕКСАМИ ВІЙСЬК ПРОТИПОВІТРЯНОЇ ОБОРОНИ СУХОПУТНИХ ВІЙСЬК НА ПОЛІГОНІ
}

\begin{abstract}
У статті запропонована удосконалена методика оцінки відповідності вимогам безпеки умов проведення контрольно-льотних випробувань (бойових стрільб) зенітних керованих ракет до зенітних ракетних комплексів військ протиповітряної оборони Сухопутних військ Збройних Сил України на полігоні. Удосконалена методика дає змогу оиінити вибір стартової позииії в межсах полігону на відповідність вимогам керівних документів, щчо регламентують порядок проведення випробувань (бойових стрільб). Запропоновано варіант оцінювання імовірності падіння аварійної ракети на населені пункти, військові, господарчі та інші об'єкти, які потрапили до зон небезпеки зенітного ракетного комплексу. В якості критерію для оцінки відповідності вимогам безпеки умов проведення контрольно-льотних випробувань (бойових стрільб) використовується критерій прийнятного ризику.
\end{abstract}

Ключові слова: зенітний ракетний комплекс, методика, вимоги безпеки, зони небезпеки, критерій прийнятного ризику.

\section{Вступ}

Постановка проблеми. Одним з напрямків нарощування бойових спроможностей військ протиповітряної оборони (ППО) Сухопутних військ (СВ) Збройних Сил (3С) України $є$ розвиток (відновлення, ремонт, модернізація та продовження строків експлуатації) існуючих та раніше знятих з озброєння зразків озброєння і військової техніки та регулярне проведення заходів бойової підготовки, в тому числі, бойових стрільб.

Основною вимогою при проведенні контрольно-льотних випробувань та бойових стрільб є забезпечення безпеки цих заходів. Безпека проведення контрольно-льотних випробувань (бойових стрільб) зенітних керованих ракет (ЗКР) до зенітних ракетних комплексів (ЗРК) ППО СВ та бойових стрільб частин і підрозділів ППО СВ може бути оцінена шляхом розрахунку зон небезпеки для зазначених ЗРК та оцінки імовірності падіння аварійної ракети на населені пункти, військові, господарчі та інші об'єкти, які потрапили до зон небезпеки зенітного ракетного комплексу.

Аналіз останніх досліджень і публікацій. В даний час, основним офіційним документом, що регламентує порядок проведення розрахунків зон небезпеки, є Стандартна методика оцінки безпеки проведення військових навчань із застосуванням зброї (далі - Стандартна методика) [1] 3 доповненнями. Основним призначенням Стандартної методики $\epsilon$ визначення просторових параметрів зон безпе- ки, в межах яких забезпечується безпека перебування людей, бойової та іншої техніки, запобігається збиток господарчим та іншим об'єктам при проведенні навчань з бойовими пусками ракет та випробувань.

Разом 3 тим, зазначена Стандартна методика не відповідає вимогам інших керівних документів, щодо імовірності вильоту аварійної ракети за межі зони небезпеки та не дозволяс розрахувати імовірність падіння аварійної ракети на населені пункти, військові, господарчі та інші об'єктів, які потрапили до зон небезпеки зенітного ракетного комплексу.

В роботі [2], був запропонований один 3 можливих варіантів визначення імовірності падіння аварійної ракети на населені пункти, військові, господарчі та інші об'єкти в межах зони небезпеки зенітного ракетного комплексу.

Існує й інший підхід до визначення меж зон небезпеки. Як свідчить досвід проведення розрахунків зон небезпеки для ЗРК “Бук М1”, С-300П [3-4], для більш точного розрахунку їх меж потрібно мати математичну модель наведення зенітних керованих ракет (ЗКР) на ціль, а для розрахунків відповідних ймовірностей необхідно знати характеристики надійності станції наведення ракет та бортового обладнання. На теперішній час такі моделі для ЗРК військ ППО СВ не відомі, а їх створення потребує наявності даних зовнішньо-траєкторних вимірювань та характеристик контуру управління ЗРК.

Метою статті є розробка удосконаленої мето- 
дики оцінки відповідності вимогам безпеки умов проведення контрольно-льотних випробувань (бойових стрільб) зенітних керованих ракет до зенітних ракетних комплексів військ протиповітряної оборони Сухопутних військ Збройних Сил України на полігоні.

\section{Виклад основного матеріалу}

Зона небезпеки при проведенні навчань з бойовими пусками ракет - територія, в межах якої перебування людей загрожує їх життю, а бойовій та іншій техніці, господарчим та іншим об'єктам може бути завдано збиток [1].

Порядок розрахунку зони небезпеки для озброєння військ ППО СВ викладені у частині 3 Стандартної методики [1]. Відповідно до зазначеної методики, для визначення просторових параметрів зон безпеки під час проведення навчань з бойовими пусками ракет попередньо розраховуються розміри зон небезпеки за такими просторовими показниками: дальністю та параметром. Розсіювання точок падіння ракет в горизонтальній площині описується еліпсом, межі якого і визначають загальний вигляд зони небезпеки у наземному просторі при пусках ракет конкретного типу. Імовірність падіння ракет у визначений еліпс складає 0,99 , відповідно імовірність вильоту аварійної ракети або ï уламків (решток), осколків від спрацювання бойового спорядження за межу зони небезпеки складає $1 \times 10^{-2}$.

Отже, у Стандартній методиці точка падіння ракети у горизонтальній площині розглядається як двовимірна випадкова величина $N$, яка підпорядковується нормальному закону розподілення, а зона небезпеки у наземному просторі при пусках ракет являє собою ні що інше як еліпс рівних імовірностей.

Для відображення зони небезпеки введемо декартову систему координат у наземному просторі, яка пов'язує точку стояння (стартову позицію) ЗРК та напрямок стрільби, який залежить від параметрів руху мішені (рис. 1).

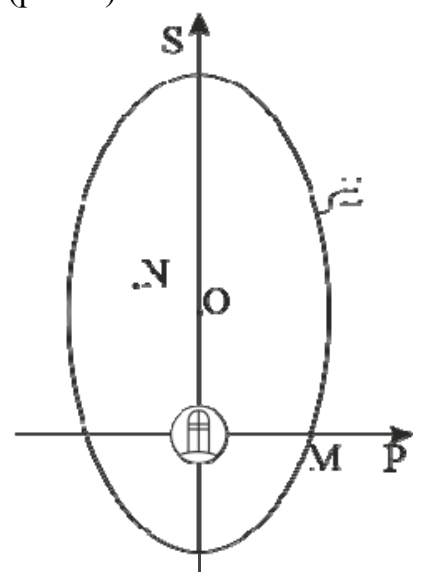

Рис. 1. Загальний вигляд зони небезпеки ЗРК Джерело: розроблено авторами за даними $[1$, c. 8$]$.
Вісь ординат $S$ спрямуємо у основному напрямку стрільби, вісь абсцис $P$ перпендикулярно осі $S$. В такій системі координат точка падіння ракети буде визначатися курсовою дальністю $s$ та параметром $p$, тобто $N(p, s)[5]$.

Канонічне рівняння еліпса у введеній декартовій системі координат з центром еліпса, який зміщений у точку $O\left(p_{0}, s_{0}\right)$ (рис. 1$)$, а велика вісь лежить на осі ординат має наступний вигляд [6]:

$$
\frac{\left(s-s_{0}\right)^{2}}{a^{2}}+\frac{\left(p-p_{0}\right)^{2}}{b^{2}}=1,
$$

де $a$-велика піввісь еліпсу;

$b$ - мала піввісь еліпсу.

3 іншого боку, еліпс розсіювання точок падіння ракет являє собою еліпс рівних імовірностей, який у прийнятій системі координат описується виразом [6-7]:

$$
\frac{\left(s-s_{0}\right)^{2}}{\sigma_{s}^{2}}+\frac{\left(p-p_{0}\right)^{2}}{\sigma_{p}^{2}}=\mu^{2},
$$

де $\sigma_{s}, \sigma_{p}$ - середнє квадратичне відхилення (СКВ) координат $s$ i $p$ точок падіння ракет.

Величини $\sigma_{s}$ i $\sigma_{p}$ характеризують розсіювання точок падіння ракет у напрямку осей прийнятої системи координат, тобто за курсовою дальністю та параметром. Математичне очікування (МО) (центри розсіювання) випадкових величин $S, P$, знаходиться у точці $O\left(0, D_{\max }\right)$ (рис. 1$)$.

Згідно вимог інших керівних документів при розрахунках зони небезпеки мають враховуватися такі вимоги:

- імовірність вильоту аварійної ракети або іiі уламків (решток), осколків від спрацювання бойового спорядження за межу зони небезпеки не повинна перевищувати $1 \times 10^{-4}$;

- імовірність попадання аварійної ракети або іiі уламків (решток), осколків від спрацювання бойового спорядження на населені пункти або інші об'єкти в межах зони небезпеки не повинна перевищувати $1 \times 10^{-4}$.

Отже, виникає необхідність приведення положень Стандартної методики до вимог інших керівних документів.

Імовірність потрапляння точки падіння ракети $N(p, s)$ в еліпс $E$ (рис. 1) розраховується за формулою [6]:

$$
P\{N \in E\}=1-e^{-\frac{k^{2}}{2}},
$$

де $k=\frac{a}{\sigma_{s}}=\frac{b}{\sigma_{p}}$.

В Стандартній методиці ця імовірність задана 
на рівні 0,99 [1]. Підставивши це значення у вираз (3) можна знайти значення $k$ i, відповідно, значення СКВ точок падіння ракет.

Введемо додаткову змінну $x=\frac{k^{2}}{2} .3$ урахуванням цієї змінної та зробивши необхідні перетворення, вираз (3) напишемо у наступному вигляді:

$$
e^{-x}=10^{-2} \text {. }
$$

Вираз (4) являє собою імовірність вильоту ракети за межі еліпсу розсіювання. Використовуючи властивості експоненти напишемо вираз для $x$ :

$$
x=\ln \left(\frac{1}{10^{-2}}\right) \text {. }
$$

Отже, знайшовши значення $x$ при відомих $a$ i $b$ за виразом (5), можна віднайти значення СКВ координат $s$ i $p$ точок падіння ракет $-\sigma_{s}, \sigma_{p}$ відповідно.

При відомих значеннях СКВ і, відповідно, дисперсій нормального закону розподілення двовимірної випадкової величини координат точка падіння ракети $N(p, s)$ можна віднайти значення великої $a$ та малої $b$ півосей для еліпсу рівних імовірностей, який забезпечує імовірність вильоту аварійної ракети або ії̈ уламків (решток), осколків від спрацювання бойового спорядження за межу зони небезпеки на рівні $1 \times 10^{-4}$. Для цього необхідно вирішити рівняння (5) при відомих $\sigma_{s} \mathrm{i} \sigma_{p}$, прирівнявши значення знаменника у дужках до $10^{-4}$.

Отже, з урахуванням вимог керівних документів, методика розрахунку зони небезпеки ЗРК при проведенні контрольних льотних випробувань (бойових стрільб) може бути викладена наступним чином:

- в залежності від характеристик мішеней (швидкість та висота польоту), їх маршруту польоту розраховуються параметри зони ураження, будується горизонтальний переріз зони ураження для визначеної висоти (висот) польоту мішеней, відносно неї визначаються межі бойової зони та забороненої зони;

- визначаються просторові параметри зони небезпеки, яка забезпечує необхідну імовірність падіння аварійної ракети та іiї межі на місцевості;

- визначаються межі дозволеного сектору стрільби в межах зони небезпеки;

- проводиться оцінка кількості та характеристик об'єктів інфраструктури, військових об'єктів тощо, що входять до зони небезпеки;

- визначається імовірність падіння аварійної ракети в межах зони небезпеки на визначені об'єкти інфраструктури та інші об'єкти.

Один 3 можливих варіантів обчислення цієї імовірності викладено в [2]. Отримане значення імовірності порівнюється 3 встановленим пороговим значенням і приймається рішення щодо можливості чи неможливості проведення стрільб з визначених СП. У разі неможливості проведення стрільб з визначених СП з міркувань безпеки, проводяться додаткові дослідження, які направлені на зменшення імовірності падіння аварійної ракети в межах зони небезпеки на визначені об'єкти інфраструктури та інші об'єкти. Основними способами зменшення імовірності падіння аварійної ракети є перенесення СП, перенесення об'єктів інфраструктури, їх додатковий захист та/або страхування;

- при виконанні умов пункту 5 даної методики, проводяться розрахунки зон закриття повітряного та морського простору при проведенні бойових стрільб.

Порядок розрахунку параметрів зони небезпеки згідно наведеної методики.

1. Розрахунок параметрів та побудова горизонтального перерізу зони ураження для обраного типу ЗРК та визначених типів мішеней.

Вхідні дані:

- швидкість польоту мішені $V M$;

- висота польоту мішені $H$ м;

- кут нахилу вектору швидкості мішені до горизонту $\lambda$.

Визначаються ближня, дальня межа горизонтального перерізу зони ураження ЗРК та граничний курсовий параметр мішені для вихідних параметрів польоту мішені. Ці параметри зони ураження визначатимуть межі бойової та забороненої зон.

2. Визначення просторових параметрів зони небезпеки, яка забезпечує необхідну імовірність падіння аварійної ракети та їі межі на місцевості.

Із аналізу отриманих в пункті 1 даної методики даних, визначається максимальна горизонтальна дальність ураження комплексу - $D_{\max }$ для заданих параметрів руху мішені. Розрахунок значень великої півосі $a$ та малої півосі $b$ еліпсу розсіювання точок падіння аварійних ракет з імовірністю 0,99 здійснюється за формулами:

$$
\begin{gathered}
a=2 D_{\max } ; \\
b= \pm \frac{2 D_{\max }}{\sqrt{3}} .
\end{gathered}
$$

Визначаємо середнє квадратичне відхилення (CКВ) точок падіння аварійних ракет в системі координат $s, p$, де вісь ординат $s$ спрямована у напрямку стрільби і являє собою курсову дальність, а вісь абсцис $p$ - перпендикулярна осі $s$ і являється курсовим параметром. СКВ точок падіння аварійної ракети за координатами $s, p$ визначаються за виразами:

$$
\sigma_{s} \approx \frac{a}{3,035}
$$




$$
\sigma_{p} \approx \frac{b}{3,035} .
$$

За відомими значеннями СКВ проводиться розрахунок геометричних параметрів еліпсу розсіювання, в межах якого забезпечується падіння ракет 3 імовірністю 0,9999 (імовірність вильоту аварійної ракети за межі еліпсу розсіювання $10^{-4}$ ). Розрахунок значень великої півосі $a_{0,9999}$ та малої півосі $b_{0,9999}$ еліпсу розсіювання, в межах якого забезпечується падіння ракет з імовірністю 0,9999 проводиться за формулами:

$$
\begin{aligned}
& a_{0,9999} \approx 4,292 \sigma_{s} ; \\
& b_{0,9999} \approx 4,292 \sigma_{p} .
\end{aligned}
$$

Центр еліпсу розсіювання відносно місця розташування СП буде знаходитись на основному напрямку стрільби на віддалені:

$$
s_{0}=\sqrt{a_{0,9999}^{2}-b_{0,9999}^{2}} .
$$

Змінюючи значення координати $p$ від 0 до $b_{0,9999}$, знаходяться відповідні координати s еліпса розсіювання падіння аварійних ракет

$$
s= \pm \frac{a}{b} \sqrt{b^{2}-p^{2}}+s_{0} .
$$

Утворений масив значень координат $p, s$ характеризують межі еліпсу розсіювання точок падіння аварійних ракет у просторі відносно СП.

Максимальна дальність падіння ракети $D_{\text {nad }}^{\text {Д }} 3$ урахуванням підриву бойової частини в точці падіння визначається за формулою

$$
D_{\text {nad }}^{\text {Д }}=a+\sqrt{a^{2}-b^{2}} .
$$

Розміри зони небезпеки за параметром $D_{\text {небез }}^{\text {ПАР }}$ визначається виразом

$$
D_{\text {небез }}^{\text {ПАР }}=\frac{b^{2}}{a} .
$$

Максимальна відстань до межі тилової частини зони небезпеки $D_{\text {небез }}^{\text {TИл }}$ складає

$$
D_{\text {небез }}^{\text {ТИЛ }}=a-\sqrt{a^{2}-b^{2}} .
$$

При вертикальному старті зенітних керованих ракет, за потреби, тилова частина зони небезпеки може бути апроксимована колом з радіусом $D_{\max }$.

3. Визначення меж дозволеного сектору стрільби в межах зони ураження.

У будь-якому випадку спочатку доцільно визначити мінімально необхідний дозволений сектор стрільби. Під мінімально необхідним сектором розуміється такий, що забезпечує можливість обстрілу мішені на усьому відрізку іiї польоту в зоні ураження ЗРК. Для визначення меж дозволеного сектору стрільби необхідно обрати основний напрямок стрільби ЗРК, який найбільш доцільний для даних умов полігону. Визначити межі смуги можливих трас польоту мішеней за курсовим параметром відносно обраного напрямку. Ці межі характеризуються максимальним відхиленням курсового параметру $P$ від заданої величини. Для радіокерованої мішені це відхилення $\Delta P$ дорівнює максимальній помилці виводу мішені на задану трасу польоту. Отже, відхилення траєкторій польоту мішеней відносно обраного напрямку утворює "коридор" шириною $P \pm \Delta P$. Точки перетину меж даного “коридору” з ближньою межею ЗУ дають шукані пеленги меж дозволеного сектору стрільби відносно обраного напрямку. В більш загальному випадку, пеленги меж дозволеного сектору стрільби відносно обраного напрямку можуть визначатися точками перетину граничного курсового параметру в горизонтальній площині на заданій висоті з ближньою межею ЗУ на тій самій висоті польоту мішені. Значення кута пеленгу $\alpha$ можна визначити із співвідношення:

$$
\alpha=\operatorname{arctg} \frac{\Delta P}{D_{\min }},
$$

де $\Delta P$ - значення максимального відхилення курсового параметру польоту мішені або граничного курсового параметру відносно обраного напрямку стрільби;

$D_{\min }$ - курсова дальність до ближньої межі ЗУ на обраному напрямку стрільби.

4. Оцінка кількості та характеристик об'єктів інфраструктури, військових об'єктів, тощо, що входять до зони небезпеки здійснюється за картами, знімками з обов'язковим уточненням на місцевості. В ході оцінки кількості та характеристик об'єктів інфраструктури, військових об'єктів визначається їх площа та ступінь накриття зоною небезпеки, можливість їх захисту, важливість (критичність).

5. Визначення імовірності падіння аварійної ракети в межах зони небезпеки на визначені об'єкти інфраструктури та інші об'єкти.

Імовірність падіння $P_{H П}$ аварійної ракети на визначені об'єкти інфраструктури та інші об'єкти в межах зони небезпеки ЗРК оцінюється наступним чином:

$$
P_{H \Pi}=p_{1 x 1} \cdot S_{\Sigma H \Pi},
$$

де $p_{1 x 1}$ - щільність ймовірності падіння аварійних ракет в зоні небезпеки;

$S_{\Sigma \text { нп }}$ - загальна площа визначення об'єктів інфраструктури та інших об'єктів в межах зони небезпеки. Умовна щільність ймовірності $p_{1 x 1 / H Ш}$ при виникненні нештатної ситуації (НШ) може бути оцінена як:

$$
p_{1 x 1 / H W}=\frac{P_{e}}{S},
$$


де $P_{e}$ - ймовірність падіння ракет у визначений еліпс розсіювання точок падіння ракет в горизонтальній площині;

$S$ - площа еліпсу розсіювання точок падіння ракет в горизонтальній площині.

В свою чергу, безумовна ймовірність визначається за формулою

$$
p_{1 x 1}=p_{1 x 1 / H W} \cdot P_{H W},
$$

де $P_{H Ш}-$ ймовірність виникнення НШ.

Ймовірність виникнення нештатної ситуації може бути знайдена із виразу:

$$
P_{H u}=1-K_{Б \Gamma},
$$

де $K_{Б Г}-$ коефіцієнт бойової готовності.

Таким чином, 3 урахуванням виразів (19)-(21) визначення ймовірності падіння $P_{H П}$ аварійної ракети на визначені об'єкти інфраструктури та інші об'єкти в зоні небезпеки ЗРК визначається за виразом:

$$
P_{H \Pi}=\frac{P_{e}}{S} \cdot\left(1-K_{Б \Gamma}\right) \cdot S_{\Sigma н n} .
$$

У виразі (22) складова $\frac{P_{e}}{S} \cdot\left(1-K_{Б Г}\right)$ задає щільність ймовірності падіння аварійних ракет в зоні небезпеки $p_{1 x 1}$. Площа еліпсу розсіювання точок падіння ракет в горизонтальній площині обраховується за відомою формулою [4] $S=\pi a b$, де $a$ та $b$ велика та мала півосі еліпсу. Обчислені за виразом (22) ймовірності падіння аварійної ракети на населені пункти, військові, господарчі та інші об'єкти в зоні небезпеки ЗРК перевіряються на відповідність вибраному критерію прийнятного ризику.

\section{Висновки}

Запропонована методика оцінки відповідності вимогам безпеки вибраних стартових позицій ЗРК на полігоні при заданому критерії прийнятного ризику дає можливість оцінити можливість проведення бойових пусків ЗРК з конкретних стартових позицій 3 огляду на дотримання заходів безпеки.

За результатами попередніх розрахунків визначено просторові параметри зон небезпеки при проведенні випробувань (бойових стрільб) зенітних керованих ракет до зенітних ракетних комплексів ППО СВ. Визначення остаточних результатів розрахунків можливе лише після проведення детальної рекогносцировки на місцевості.

В подальшому, для більш точного визначення параметрів зон небезпеки для ЗРК військ ППО СВ необхідно створювати імітаційні моделі зенітних керованих ракет, визначати перелік можливих нештатних ситуацій і ймовірностей їх виникнення та проводити моделювання польоту ракет з врахуванням нештатних ситуацій.

\section{Список літератури}

1. Стандартна методика оцінки безпеки проведення військових навчань із застосуванням зброї. Кн. 1. Київ : ГШ 3СУ, 2003. $62 \mathrm{c}$.

2. Мегельбей В. В. Методика оцінки відповідності вимогам безпеки вибраних стартових позицій зенітних ракетних комплексів військ ППО Сухопутних військ на полігоні. Наука і техніка Повітряних Сил Збройних Сил Украӥни. 2015. № 4(21). С. 107-109.

3. Ведмідь О. І. Практичний критерій для розрахунків меж зони небезпеки при стрільбі керованою зброєю на полігонах. Системи озброєння і військова техніка. 2012. № 2(30). С. 26-29.

4. Бархударян М. В., Бурцев В. В., Ведмідь О. І., Кліменков С. В. Типові нештатні ситуації та оцінка ризиків їх виникнення при стрільбах ЗРК С-300П. Системи озброєння і військова техніка. 2009. № 3(19). С. 7-10.

5. Козаков Ю. И., Лукьянчук В. Н., Пушкорюс С. К., Тимохин В. А. Стрельба и управление огнем частей и подразделений ППО СВ. Киев : ВА ПВО СВ, 1988. 171 с.

6. Бронштейн И. Н., Семендяев К. А. Справочник по математике для инженеров и учащихся вузов. Москва : Наука, 1986. $544 \mathrm{c}$.

7. Абезгауз Г. Г., Тронь А. П., Копенкин Ю. Н., Коровина И. А. Справочник по вероятностным расчетам. Москва : Воениздат, 1970. $536 \mathrm{c}$.

8. Вентцель Е. С. Введение в исследование операций. Москва : Советское радио, 1964. 389 с.

9. Мегельбей В. В., Мегельбей Г. В., Кулагін К. К., Бархударян М. В. Шляхи удосконалення методики підготовки та проведення комплексних навчань військ з бойовою стрільбою. Наука і техніка Повітряних Сил Збройних Сил Украйни. 2014. № 1(14). С. 47-51.

10. Lukianchuk V. Lanetskii B., Khudov H., Zvieriev O., Terebuha I., Kuprii V., Artemenko A., Aristarkhov O., Kondratenko Y. Development of the combined method for evaluating and controlling the reliability indicator "probability of failure-free switching" of a radio technical complex. Eastern-European Journal of Enterprise Technologies. 2021. No. 1/9(109). P. 6-17.

11. Бархударян М. В., Мішуков О. М., Чумак Б. О. Визначення основних тактико-технічних характеристик вимірювальних засобів полігонного вимірювально-обчислювального комплексу, які впливають на рівень безпеки при проведенні бойових стрільб, пусків ракет, бомбометання та полігонних випробувань. Системи озброєння $і$ військова техніка. 2010. № 3(23). C. 19-21. 
Відомості про авторів:

Мегельбей В'ячеслав Вікторович кандидат технічних наук начальник науково-дослідної лабораторії Харківського національного університету Повітряних Сил ім. І. Кожедуба,

Харків, Україна

https://orcid.org/0000-0001-7785-765X

Нєкрасов Сергій Володимирович молодший науковий співробітник

Харківського національного університету

Повітряних Сил ім. І. Кожедуба,

Харків, Україна

https://orcid.org/0000-0002-5846-0136

Іценко Дмитро Сергійович

головний спеціаліст відділу планування наукової роботи Воєнно-наукового управління

Генерального штабу Збройних Сил України,

Київ, Україна

https://orcid.org/0000-0002-3545-215X

\section{Шептуха Кирило Анатолійович}

курсант

Харківського національного університету

Повітряних Сил ім. І. Кожедуба,

Харків, Україна

https://orcid.org/0000-0002-5134-372X
Information about the authors:

Viacheslav Mehelbei

$\mathrm{PhD}$ in Engineering

Head of Scientific Research Laboratory

of Ivan Kozhedub Kharkiv National

Air Force University,

Kharkiv, Ukraine

https://orcid.org/0000-0001-7785-765X

Sergiy Nyekrasov

Junior Researcher

of Ivan Kozhedub Kharkiv National

Air Force University,

Kharkiv, Ukraine

https://orcid.org/0000-0002-5846-0136

\section{Dmitry Itsenko}

Chief Specialist of the Scientific Work Planning Department of Military Scientific Directorate of General Staff

of Armed Force of Ukraine,

Kyiv, Ukraine

https://orcid.org/0000-0002-3545-215X

Kyrylo Sheptukha

Cadet

of Ivan Kozhedub Kharkiv National

Air Force University,

Kharkiv, Ukraine

https://orcid.org/0000-0002-5134-372X

\title{
МЕТОДИКА ОЦІНКИ ВІДПОВІДНОСТІ ВИМОГАМ БЕЗПЕКИ УМОВ ПРОВЕДЕННЯ БОЙОВИХ СТРІЛЬБ ЗЕНІТНИМИ РАКЕТНИМИ КОМПЛЕКСАМИ ВІЙСЬК ПРОТИПОВІТРЯНОЇ ОБОРОНИ СУХОПУТНИХ ВІЙСЬК НА ПОЛІГОНІ
}

В.В. Мегельбей, С.В. Некрасов, Д.С. Иценко, К.А. Шептуха

В статье предложена методика оиенивания соответствия требованиям безопасности выбранных стартовых позиций зенитных ракетных комплексов на полигоне при заданном критерии. В случае попадания в зоны опасности зенитных ракетных комплексов населенных пунктов, военных, хозяйственных или других объектов методика дает возможность оченить выбор стартовой позичии на соответствие выдвинутому критерию с учетом требований руководящих документов. В качестве критерия для оченки соответствия требованиям безопасности выбранных стартовых позииий используется критерий допустимого риска.

Ключевые слова: зенитный ракетный комплекс, методика, требования безопасности, зоны опасности, допустимый риск.

\section{METHOD EVALUATION OF CONFORMITY SECURITY CONDITIONS OF CONTROL-FLIGHT TESTS (COMBAT SHOOTING) ANTI-AIRCRAFT GUIDED MISSILES TO AIR DEFENSE SYSTEMS OF AIR DEFENSE TROOPS OF GROUND FORCES IN A SHOOTING RANGE}

\author{
V. Mehelbei, S. Nyekrasov, D. Itsenko, K. Sheptukha
}

The article proposes to improve the methodology for assessing compliance with safety requirements of the conditions of control and flight tests (combat firing) of anti-aircraft guided missiles to anti-aircraft missile systems of the air defense forces of the Land Forces of the Armed Forces of Ukraine at the test site. Improved methodology makes it possible to assess the choice of starting position within the range for compliance with the requirements of the governing documents governing the procedure for testing (combat shooting). A variant of estimating the probability of an emergency missile falling on settlements, military, economic and other objects that fell into the danger zones of the anti-aircraft missile system is proposed. The criterion of acceptable risk is used as a criterion for assessing compliance with the safety requirements of the conditions of flight control tests (combat firing). Danger zone during exercises with combat missile launches - an area within which the presence of people threatens their lives, and combat and other equipment, household and other facilities may be damaged. The point $N$ of impact of the missile in the horizontal plane is considered as a two-dimensional random variable, which obeys the normal law of distribution, and the danger zone in ground space is an ellipse of equal probabilities. The following requirements must be taken into account when calculating the danger zone: the probability of departure of an emergency missile or its fragments (remains), fragments from the operation of combat equipment outside the danger zone should not exceed the criterion of acceptable risk; the probability of hitting an emergency missile or its fragments (remains), fragments from the operation of combat equipment on settlements or other objects within the danger zone should not exceed the criterion of acceptable risk. Existing techniques allow to calculate the parameters of the danger zone when the value of the criterion of acceptable risk $1 \times 10^{-2}$ and don 't allow to calculate the probability of hitting an emergency missile or its fragments (remains), fragments from the operation of combat equipment on settlements or other objects within the danger zone. The article considers one of the possible options for calculating the parameters of the danger zone when the value of the criterion of acceptable risk $1 \times 10^{-4}$ and option to calculate the probability of an emergency missile falling on various objects within the danger zone.

Keywords: antiaircraft missile complex, methodology, safety requirements, danger zones, allowed risk. 